which has a semi-polar double bond is supported by evidence derived from the parachor. Among less familiar substances described are the somewhat evanescent compound nitroxyl, $\mathrm{NOH}$, which polymerizes to hyponitrous acid, and pernitrous acid, $\mathrm{O}: \mathrm{N} . \mathrm{O} . \mathrm{OH}$, an isomer of nitric acid, arising from the interaction of hydrogen peroxide and sodium nitrite.

Compounds of the radical ammonium are so numerous and important that a whole volume has been devoted to its consideration. Sir Humphry Davy was the first to use the term ammonium and to point out its metallic properties, in particular its power of forming an amalgam, although the free radical is not yet known. That the ion has a tetrahedral structure was deduced by W. H. Mills from the optical activity of its quaternary salts. The present issue (Lief. 1) contains a full account of investigations of the system $\mathrm{NH}_{3}: \mathrm{H}_{2} \mathrm{O}$ and of the difficult problems connected with the basicity of ammonia. The extensive use of ammonium nitrate as an important constituent of high explosives was responsible for much work upon the properties of this polymorphic salt, a useful summary of which has been included.

(4 and 5). The production of special surface coatings to aluminium has become so important industrially that a whole part $(A 3)$ is devoted to it, while numerous alloys of aluminium are described in another part $(A 4)$. Both metals and non-metals are used for surfacing the metal, but whereas the former are chiefly used for decorative effects, the latter are mainly protective and greatly increase the usefulness of aluminium. Of particular interest is the electrochemical oxidation of the surface, the chief electrolytes used being chromic acid (in England), oxalic acid (in Germany and Japan) and sulphuric acid (in America). The last-named process is particularly adapted to the application of organic dyes to the oxide layer.

Alloys of aluminium have also attracted the attention of research workers in recent years to such an extent that some deviation from the general plan of the handbook has been adopted in order to collect together all those alloys which contain more than 50 per cent of aluminium. Special attention is given to alloys with silicon, which mixes with aluminium in all proportions in the liquid state, a simple eutectic system resulting on solidifying. The texture of the valuable eutectic alloy can be greatly improved by the addition of sodium or sodium fluoride.

(6) The technical uses of uranium are still very small in comparison with the amount of material rendered available as by-products in the extraction of radium. Uranium is used as a catalyst in the synthesis of ammonia, in the manufacture of steel, glass and ceramics and in dyeing and photography. A summary is given of the investigation of its isotopes, particularly of actino-uranium, with a probable atomic mass of 235 , and of the synthetic radio elements beyond uranium.

\title{
Mohammedan Marriage Customs
}

Marriage Conditions in a Palestinian Village By Dr. Hilma Granqvist. Vol. 1. Pp. vi +200. 75 Fmk. Vol. 2. (Societas Scientiärum Fennica : Commentationes Humanarum Litterarum, III, 8 and VI, 8.) Pp. 366. 160 Fmk. (Helsingfors: Akademische Buchhandlung; Leipzig : Otto Harrassowitz, 1931, 1936.)

$\mathrm{D}^{\mathrm{n}}$ R. HILMA GRANQVIST'S book is important both from a methodical point of view and on account of facts recorded in it. Her field studies were restricted to the village of Artās, situated south of Bethlehem at the edge of the Judaean desert and inhabited by Mohammedan Arabs. She examined all the information she was able to obtain regarding the marriages that had been contracted in the village during a period of a hundred years-in all, 264 marriages entered into by 199 men-and also procured information concerning a smaller number of marriages contracted by Artās women with men in other places. On the basis of her family lists she worked out statistics and compiled tables which formed a complement to the genealogical trees, and round this foundation the rest of her material was grouped.

This method has no doubt obvious advantages. The author writes: "In registering and discussing all the people in the village during four to five generations, we came upon a great many facts which would probably not otherwise have come to light, and the material appeared quite naturally, without having to be suggested in any way." On the other hand, it is a drawback that the genealogical method can be applied only to very limited areas, and it must also be admitted that it has not proved to be a key to so many doors as it has sometimes been supposed to unlock. Dr. Granqvist has widened the outlook by quoting numerous parallels or contrasts, remarks and references, found in printed sources relating both to Palestine and to 
other Mohammedan countries ; but she has wisely relegated them to footnotes in order not to blur the picture given in the text.

Most of Dr. Granquist's information was obtained from two native women recommended to her by Miss Louise Baldensperger, whose knowledge of Arțās, where she had lived more than thirty years, was "of inestimable help and value" to the author. Those two informants learned to relate so slowly that their statements could be taken down word for word. The material is thus to a large extent a direct translation of the literal reports given by the women, but very frequently the translation is followed by the Arabic original. This is particularly the case with the copious songs, proverbs and formulæ found in the text, which, consequently, also should make the book a valuable contribution to Arabic dialectology.

The importance of Dr. Granqvist's investigations is enhanced by the fact that they have been made by a woman among women. In a society where the sexes are so secluded from each other as they are in the Mohammedan world, I think that the women can be properly studied only by members of their own sex ; but in most cases the writers on Mohammedan marriage customs have been men. The author writes that those who have women as informants are in a specially favoured position, because "the women are very much interested in their conditions and linger with pleasure over things which the men glide over lightly". But as marriage is an institution in which both sexes are concerned, I also think that there are aspects of it which can be properly studied only by men.

A Mohammedan marriage is a complicated procedure, and Dr. Granqvist gives a graphic description of its successive stages. She has chapters on the age of marriage and child betrothal; the choice of a bride ; the exchange of bride for bride and the bride price ; the betrothal ceremonies and the making of the marriage contract ; preparations for the wedding; the fetching of the bride; her arrival in the bridegroom's house; and the wedding week. There are chapters on the married woman in her husband's house and on her relation to her father's house, which are the more interesting since they deal with subjects that have not generally been sufficiently noticed in the literature on Mohammedan marriages. A woman is even after her marriage closely bound to her father's house, and her position in her husband's house is dependent on the esteem she enjoys and the support she can count upon in her old home. In critical situations she takes refuge there; when she is dissatisfied with the manner in which her husband treats her or when she is divorced by him. So also she is protected by her brother: "a man is even more responsible for his sister than for his wife and children".

The people themselves are said to find with surprise how well marriage generally turns out. Polygyny is certainly a disturbing factor; there is a saying that "the co-wife is bitter even if she were honey in a jar". But polygyny is not frequent in Artas, and in one great clan altogether lacking. A reason for this is the deficiency of women, which has compelled many men to take wives from other places. The author raises the question whether this deficiency may be due to the high percentage of cousin marriages, in accordance with my finding that in various cases inbreeding is combined with an excess of males. Thus, according to statistics of 1901, the small community of Samaritans at Nablus, who never marry outside of their own body, consists of 97 males and 55 females. Divorce is even less frequent in Artās than polygyny, which is contrary to the opinions generally held about Mohammedan peoples. While of the 199 married men 26 are or have been polygynous, only 10 have divorced their wives. The author admits that the infrequency of divorce is probably connected with the poverty of the village and the small number of women, but thinks available statistics would prove that the prevalence of divorce in the Mohammedan world has been greatly exaggerated. This is an altogether exceptional case in which Dr. Granqvist's study of the little Palestinian village has led her to such far-reaching speculations. A chapter on widower and widow concludes her remarkable book, which also contains excellent illustrations from photographs taken by the author.

Edward Westermarck.

\section{Die Fermente und ihre Wirkungen}

Von Prof. Carl Oppenheimer. Supplement. Lief. 5. (Band 1: Specieller Teil: Haupt-Teil 12.) Pp. xii +641-78l. (Den Haag: Dr. W. Junk, 1936.) 10 fl.

THe fifth delivery of this supplement continues the description of those enzymes which attack proteins, namely, the proteases and peptidases. It commences with two chapters of particular and general interest, one containing a discussion of some special questions relating to protein structure and the other being devoted to the question of the simplification of the true proteins by these enzymes. Both are of considerable value at the present time, when so much is uncertain in this intricate field of knowledge, and their study, though far from easy, will be helpful for those workers who are trying to bring some clarity into the subject.

The proteases are described in some detail under the headings of their qualitative and quantitative detection and their separation. About half the volume is devoted to the properties of the peptidases from a number of different aspects. 